\title{
Micromonospora mirobrigensis sp. nov.
}

Correspondence Martha E. Trujillo mett@usal.es

\author{
Martha E. Trujillo, ${ }^{1}$ Carmen Fernández-Molinero, ${ }^{1}$ Encarna Velázquez, ${ }^{1}$ \\ Reiner M. Kroppenstedt, ${ }^{2}$ Peter Schumann, ${ }^{2}$ Pedro F. Mateos ${ }^{1}$ \\ and Eustoquio Martínez-Molina ${ }^{1}$
}

\begin{abstract}
${ }^{1}$ Departamento de Microbiología y Genética, Edificio Departamental, Lab 209, Campus Miguel de Unamuno, Universidad de Salamanca, 37007 Salamanca, Spain

${ }^{2} \mathrm{DSMZ}$ - Deutsche Sammlung von Mikroorganismen und Zellkulturen GmbH, Mascheroder Weg 1b, 38124 Braunschweig, Germany
\end{abstract}

\begin{abstract}
An actinomycete strain was recovered from a pond where radon is known to be dissolved. A polyphasic study was undertaken to identify the new isolate. The 16S rRNA gene sequence of strain WA201 ${ }^{\top}$ showed closest similarity to the type strains of Micromonospora carbonacea (98.5\%) and Micromonospora matsumotoense (98.1\%). The chemotaxonomic results confirmed the taxonomic position of the isolate in the genus Micromonospora. DNA-DNA relatedness values supported the classification of this isolate as a novel species. A number of physiological and biochemical tests were able to distinguish strain WA201' ${ }^{\top}$ from its closest phylogenetic

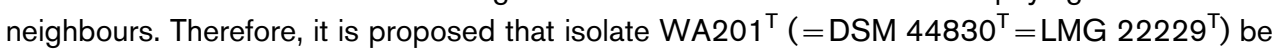
considered the type strain representing a novel species, Micromonospora mirobrigensis sp. nov.
\end{abstract}

Representatives of the genus Micromonospora (Ørskov, 1923) are reported to inhabit soil, water, marine environments and sediments (Lüdemann \& Brodsky, 1963; Kawamoto, 1989). Micromonospora endolithica, isolated from an extreme Antarctic sandstone environment, has been described recently (Hirsch et al., 2004), showing that this genus is distributed in very different environments. Kasai et al. (2000) redefined and reduced the genus to 14 species based on DNA-DNA relatedness, $16 \mathrm{~S}$ rRNA and gyrB phylogenetic data. We report the classification of an organism representing a novel Micromonospora species.

Isolate $\mathrm{WA} 201^{\mathrm{T}}$ was recovered from a water sample of a pond, located on a former uranium mine (Ciudad Rodrigo, Spain) where radon is known to be dissolved in water (Lozano et al., 2002). The isolation procedure using soil extract agar $\mathrm{pH} 6.5$ at $28{ }^{\circ} \mathrm{C}$ was described previously by Trujillo et al. (2004). Long-term maintenance of strain WA $201^{\mathrm{T}}$ was accomplished by storage in glycerol suspension $(20 \%, \mathrm{w} / \mathrm{v})$ at $-80{ }^{\circ} \mathrm{C}$. The isolate was cultured on Bennett's agar, glucose-yeast extract agar and nutrient agar to check for growth rate. Growth was slow on these media and therefore a basal medium (SA1) was designed to

Published online ahead of print on 5 November 2004 as DOI 10.1099/ ijs.0.63361-0.

Abbreviation: DAP, diaminopimelic acid.

The GenBank/EMBL/DDBJ accession number for the 16S rRNA gene sequence of strain WA201 ${ }^{\top}$ is AJ626950.

Cellular fatty acid profiles and an extended phylogenetic dendrogram are available as supplementary material in IJSEM Online. improve it. SA1 contained glucose, $10 \mathrm{~g}$; yeast extract (Difco), $3 \mathrm{~g}$; tryptone (Difco), $5 \mathrm{~g}$; tryptose (Difco), $2 \mathrm{~g}$; starch (Fluka), $2 \mathrm{~g} ; \mathrm{CaCO}_{3}, 100 \mathrm{mg} ; \mathrm{CoCl}_{2}$, traces; ferric citrate, traces; Bacto-agar (Difco), 18 g; and distilled water, 11 . The pure culture was then routinely grown on SA1 agar.

Extraction of genomic DNA, PCR amplification of the 16S rRNA gene and sequencing of the purified PCR products were described previously (Rivas et al., 2003). The sequence of isolate $\mathrm{WA} 201^{\mathrm{T}}$ was manually aligned and compared with representative sequences of members of the order Actinomycetales obtained from GenBank/EMBL. Phylogenetic distances were calculated with the Kimura twoparameter model and tree topologies were inferred using the least-squares (De Soete, 1983), maximum-parsimony (Fitch, 1972) and neighbour-joining methods (Saitou \& $\mathrm{Nei}, 1987)$. One thousand bootstrap replications were performed using the MEGA program as described by Kumar et al. (2001).

Morphological features were studied on glucose-yeast extract agar, nutrient agar and SA1 agar at $28^{\circ} \mathrm{C}$. Cell morphology and motility were observed by phase-contrast microscopy using 5 -day-old cultures. Spore production was examined on 3-week-old cultures on SA1 agar using a scanning electron microscope (Zeiss, DSM 940). Agar plugs were fixed overnight in phosphate buffer $(\mathrm{pH} \mathrm{7 \cdot 0)}$ which contained $2 \%$ paraformaldehyde and $0 \cdot 2 \%$ glutaraldehyde, dehydrated through a graded ethanol series, critical-point dried and sputter-coated with gold. The Gram and acid-fast stains (Doetsch, 1981) were performed using 3-day-old cultures. 
The ability of isolate $\mathrm{WA} 201^{\mathrm{T}}$ to grow on a range of sole carbon sources at $1 \%(\mathrm{w} / \mathrm{v})$ was determined according to Williams et al. (1983) with agar and a nitrogen base without amino acids (Difco). $\mathrm{NaCl}$ tolerance and temperature $\left(4-45^{\circ} \mathrm{C}\right)$ growth ranges were determined on SA1 medium.

Isolate $\mathrm{WA}^{2} 01^{\mathrm{T}}$ and Micromonospora carbonacea DSM $43168^{\mathrm{T}}$ were also characterized using the API $20 \mathrm{NE}$ and API ZYM systems (bioMerieux) according to the manufacturer's instructions and incubation of the strips for $48 \mathrm{~h}$ at $28^{\circ} \mathrm{C}$. Catalase and oxidase activity were recorded as described previously (Rivas et al., 2003). Hydrolysis of casein ( $1 \%$ skimmed milk), aesculin, arbutin, starch ( $1 \%$ $\mathrm{w} / \mathrm{v})$, tyrosine $(0 \cdot 5 \%)$ and xylan $(0 \cdot 4 \%)$ were tested on SAl as the basal medium.

Susceptibility to various antibiotics was examined for the isolate and M. carbonacea DSM $43168^{\mathrm{T}}$ using amikacin $(30 \mu \mathrm{g})$, amoxicillin/clavulanic acid $(20 / 10 \mu \mathrm{g})$, ampicillin $(2 \mu \mathrm{g})$, cefaclor $(30 \mu \mathrm{g})$, cefazolin $(30 \mu \mathrm{g})$, ciprofloxacin $(5 \mu \mathrm{g})$, cloxacillin $(1 \mu \mathrm{g})$, cefuroxime $(30 \mu \mathrm{g})$, erythromycin $(2$ and $15 \mu \mathrm{g})$, gentamicin $(10 \mu \mathrm{g})$, neomycin $(5 \mu \mathrm{g})$, netilmicin $(30 \mu \mathrm{g})$, oxacillin $(1 \mu \mathrm{g})$, oxytetracycline $(30 \mu \mathrm{g})$, penicillin $\mathrm{G}(10 \mathrm{U})$, piperacillin $(100 \mu \mathrm{g})$, polymyxin B (300 IU), tetracycline $(30 \mu \mathrm{g})$ and vancomycin $(30 \mu \mathrm{g})$ disks (Oxoid), and SA1 as the basal medium. Readings were taken at 3,5 and 10 days.

Isomers of diaminopimelic acid (DAP) in whole-cell hydrolysates were determined by TLC on cellulose (modified method of Hasegawa et al., 1983; Rhuland et al., 1955). Whole-cell sugars were analysed according to Staneck \& Roberts (1974). Menaquinones were extracted and purified by the method of Minnikin et al. (1984) and analysed by HPLC (Hewlett Packard 1100). Methyl esters of cellular fatty acids were prepared from cells grown for $24 \mathrm{~h}$ on trypticase soy agar cultures $\left(28^{\circ} \mathrm{C}\right)$ and analysed by GLC (Schröder et al., 1997). Polar lipids were extracted and identified by two-dimensional TLC (Minnikin et al., 1984). The DNA G $+C$ content was determined using the thermal melting method (Mandel \& Marmur, 1968).

DNA-DNA relatedness was measured spectrophotometrically between isolate WA $201^{\mathrm{T}}$ and M. carbonacea DSM $43168^{\mathrm{T}}$ following the method of De Ley et al. (1970) with the modification of Huß et al. (1983). DNA was purified on hydroxyapatite as described by Cashion et al. (1977). Renaturation rates were calculated using the TRANSFER.BAS program of Jahnke (1992).

The $16 \mathrm{~S}$ rRNA gene sequence of isolate $\mathrm{WA}^{2} 01^{\mathrm{T}}$ (1517 nt) showed a close relationship with members of the family Micromonosporaceae and fell within the genus Micromonospora clade. The highest sequence similarities found were with $M$. carbonacea DSM $43168^{\mathrm{T}}(98.5 \%)$ and Micromonospora matsumotoense IFO $14550^{\mathrm{T}}(98 \cdot 1 \%)$, which correspond to 22 and 28 nucleotide differences (1473 nucleotides compared), respectively. The various tree-making algorithms yielded similar tree topologies although some of the branches varied slightly, but isolate WA $201^{\mathrm{T}}$ was always recovered in the same branch as $M$. carbonacea DSM $43168^{\mathrm{T}}$. The closest phylogenetic relatives of strain WA201 $1^{\mathrm{T}}$ are represented on the tree corresponding to the Kimura two-parameter method and the least-squares method (Fig. 1). An extended phylogenetic dendrogram is provided as Supplementary Fig. A in IJSEM Online.

Growth of strain WA201 ${ }^{\mathrm{T}}$ was slow on glucose-yeast extract agar and nutrient agar, where small colonies appeared only after 5 days, compared with SAl agar, where good growth was observed after 2 days. Colonies on the three media were orange, turning dark brown on sporulation after 10-15 days; no diffusible pigments were produced on these media. Colonies on SA1 medium were raised, folded and produced a well-developed substrate mycelium $(0 \cdot 4-$ $0.6 \mu \mathrm{m}$ diameter), but lacked aerial hyphae. The formation of single, non-motile, spherical spores $(0 \cdot 7-0 \cdot 9 \mu \mathrm{m})$ was observed. The spore surface was slightly warty and most of them occurred as short sporophores.

Strain WA201 $1^{\mathrm{T}}$ grew at between 20 and $37^{\circ} \mathrm{C}$, but no growth was recorded at $4,10,15$ or $45^{\circ} \mathrm{C}$ after 3 weeks. Tolerates $\mathrm{NaCl}$ up to $3 \%$; no growth occurred at $5 \%$. Nitrate was not reduced. The isolate hydrolysed aesculin, arbutin, casein, gelatin, starch and xylan.

WA2 $21^{\mathrm{T}}$ and M. carbonacea DSM $43168^{\mathrm{T}}$ produced the following enzymes (API ZYM kit): alkaline phosphatase, esterase lipase (C8), lipase, leucine arylamidase, valine arylamidase, cystine arylamidase, trypsin, $\alpha$-chymotrypsin, acid phosphatase, $\alpha$-galactosidase, $\beta$-galactosidase, $\beta$ glucuronidase, $\alpha$-glucosidase, $\beta$-glucosidase and $N$-acetyl$\beta$-glucosaminidase.

The above strains produced identical antibiotic profiles, which showed resistance to ampicillin $(2 \mu \mathrm{g})$ and susceptibility to amikacin $(30 \mu \mathrm{g})$, amoxicillin/clavulanic acid (20/ $10 \mu \mathrm{g})$, cefaclor $(30 \mu \mathrm{g})$, cefuroxime $(30 \mu \mathrm{g})$, cefazolin $(30 \mu \mathrm{g})$, ciprofloxacin $(5 \mu \mathrm{g})$, cloxacillin $(1 \mu \mathrm{g})$, erythromycin $(2$ and $15 \mu \mathrm{g})$, gentamicin $(10 \mu \mathrm{g})$, neomycin $(5 \mu \mathrm{g})$,

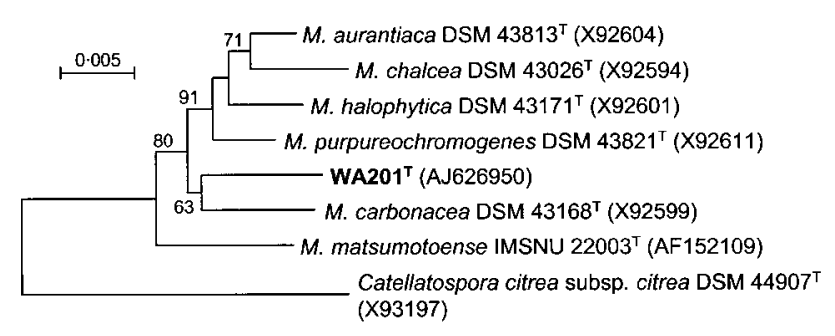

Fig. 1. Phylogenetic tree derived from 16S rRNA gene sequences showing the relationship of $M$. mirobrigensis sp. nov. WA201 ${ }^{\top}$ and related Micromonospora species. Numbers at branching points indicate percentages of occurrence using least-squares analysis applying bootstrap values above $60 \%$ based on 1000 replications. 
netilmicin $(30 \mu \mathrm{g})$, oxytetracycline $(30 \mu \mathrm{g})$, penicillin $\mathrm{G}$ $(10 \mathrm{U})$, piperacillin $(100 \mu \mathrm{g})$, polymyxin B (300 IU), oxacillin $(1 \mu \mathrm{g})$, tetracycline $(30 \mu \mathrm{g})$ and vancomycin $(30 \mu \mathrm{g})$.

Various physiological and biochemical results useful to differentiate between isolate WA2 $21^{\mathrm{T}}$ and its closest phylogenetic neighbours $M$. carbonacea DSM $43168^{\mathrm{T}}$ and $M$. matsumotoense IFO $14550^{\mathrm{T}}$ are given in Table 1. Other results are presented in the species description.

Strain WA2 $21^{\mathrm{T}}$ contained meso-DAP, which is the characteristic diamino acid of the peptidoglycan type Al $\gamma$ (Schleifer \& Kandler, 1972). Glucose in large amounts, galactose, mannose and xylose were found as whole-cell sugars. The fatty acid pattern for the isolate was composed of saturated and unsaturated iso/anteiso-branched fatty acids. A significant amount of 10-methyl-branched 17:0 $(5 \cdot 24 \%)$ was found in addition. Straight-chain saturated and unsaturated fatty acids were present only in minor amounts (Supplementary Table A). The main menaquinones were MK-10 $\left(\mathrm{H}_{4}\right)(77 \%)$ and $\mathrm{MK}-10\left(\mathrm{H}_{6}\right)(23 \%)$. A small amount of MK-9 $\left(\mathrm{H}_{4}\right)(5 \%)$ was also found. MK$10\left(\mathrm{H}_{2}\right)$ and MK-9 $\left(\mathrm{H}_{6}\right)$ occurred only as traces. This menaquinone profile differs from that reported for $M$. carbonacea DSM $43168^{\mathrm{T}}$, which contains MK-9 $\left(\mathrm{H}_{4}\right)$ in large amounts (Kawamoto, 1989), while M. matsumotoense IFO $14550^{\mathrm{T}}$ contains MK-10 $\left(\mathrm{H}_{6}\right)$, MK-10 $\left(\mathrm{H}_{8}\right)$ and MK$10\left(\mathrm{H}_{4}\right)$ in a ratio of $1 \cdot 9: 1 \cdot 8: 1$ (Lee et al., 1999). The menaquinone composition within the genus Micromonospora has been reported to be complex and heterogeneous in comparison to the menaquinone composition found in other actinomycete genera, which show similar high levels of intrageneric relatedness (Koch et al., 1996). The polar lipid pattern was mainly composed of phosphatidylinositol, phosphatidylglycerol, diphosphatidylglycerol and the

Table 1. Characteristics that differentiate strain WA $201^{\top}$ from its closest neighbours

Strains: 1 , M. mirobrigensis sp. nov. WA $201^{\mathrm{T}} ; 2$, M. carbonacea DSM $43168^{\mathrm{T}}$; 3, M. matsumotoense IFO $14550^{\mathrm{T}}$. +, Positive; -, negative; $\mathrm{W}$, weakly positive; ND, not determined.

\begin{tabular}{|lccc|}
\hline Characteristic & $\mathbf{1}$ & $\mathbf{2}$ & $\mathbf{3}$ \\
\hline$\beta$-Glucuronidase & + & - & $\mathrm{ND}$ \\
Naphthol-AS-BI-phosphate & + & - & $\mathrm{ND}$ \\
Oxidase & + & + & - \\
Urease & $\mathrm{w}$ & - & + \\
Nitrate reduction & - & + & + \\
Assimilation of: & & & \\
$\quad$ Gluconate & + & - & - \\
$\quad$ D-Melibiose & + & - & - \\
$\quad$ Histidine & + & - & $\mathrm{ND}$ \\
Tolerance of 3\% NaCl & + & + & - \\
Hydrolysis of tyrosine & - & + & $\mathrm{ND}$ \\
Major menaquinone & $\mathrm{MK}-10\left(\mathrm{H}_{4}\right)$ & $\mathrm{MK}-9\left(\mathrm{H}_{4}\right)$ & $\mathrm{MK}-10\left(\mathrm{H}_{6}\right)$ \\
\hline
\end{tabular}

diagnostic phosphatidylethanolamine. Some glycolipids of unknown structure were also found. This pattern correlates with phospholipid pattern II sensu Lechevalier et al. (1977). The $\mathrm{G}+\mathrm{C}$ content of the DNA was $68.6 \mathrm{~mol} \%$. Most chemotaxonomic markers support the placement of isolate WA2 $21^{\mathrm{T}}$ in the genus Micromonospora.

The DNA-DNA relatedness value $(36.5 \%)$ clearly indicated that isolate WA201 ${ }^{\mathrm{T}}$ does not belong to the species M. carbonacea, as this value is well below the threshold value of $70 \%$ for definition of bacterial species according to Wayne et al. (1987).

The chemical, morphological and phylogenetic data suggest that strain $\mathrm{WA} 201^{\mathrm{T}}$ represents a novel species when compared with the type strains of species with validly published names within the genus Micromonospora. Thus, on the basis of this polyphasic taxonomic study, strain $\mathrm{WA} 201^{\mathrm{T}}$ merits classification as a novel species within the genus Micromonospora and the name Micromonospora mirobrigensis sp. nov. is proposed.

\section{Description of Micromonospora mirobrigensis sp. nov.}

Micromonospora mirobrigensis (mi.ro.bri.gen'sis. N.L. fem. adj. mirobrigensis pertaining to Mirobriga, the region in Spain where the type strain was isolated).

Gram-positive, chemo-organotrophic and strictly aerobic. Colonies on SA1 agar are $2-3 \mathrm{~mm}$ in diameter after 2 weeks. Colonies are raised, folded and orange, turning brown to black on sporulation. Well-developed substrate hyphae bearing single slightly warty spores; aerial mycelium is not produced. Optimum $\mathrm{pH}$ and temperature for growth are 7 and $28^{\circ} \mathrm{C}$, respectively. Oxidase- and catalase-positive. Nitrate is not reduced; urease-negative. Growth is not observed in the presence of crystal violet $0.001 \%$ or sodium azide $0.01 \%$. Resistant to ampicillin $(2 \mu \mathrm{g})$. Acid is produced from glucose. Carbon sources assimilated are L-arabinose, D-cellobiose, D-galactose, D-glucose, D-maltose, D-mannose, D-raffinose, D-sucrose and Dtrehalose. Adipate, caprate, citrate, malate, D-mannitol, D-melezitose, phenyl-acetate, L-rhamnose, D-sorbitol, L-sorbose and xylitol are not assimilated. Contains mesoDAP in its cell wall; major menaquinone is $\mathrm{MK}-10\left(\mathrm{H}_{4}\right)$. Major fatty acids are iso-15:0, iso- $16: 0$, iso- $17: 1$ and anteiso-17:0.

The type strain, WA201 ${ }^{\mathrm{T}}\left(=\mathrm{DSM} 44830^{\mathrm{T}}=\mathrm{LMG} 22229^{\mathrm{T}}\right)$, was isolated from the region of Mirobriga (Ciudad Rodrigo, Spain).

\section{Acknowledgements}

We would like to thank Dr Jean P. Euzéby for his valuable help with naming the species. We thank the DSMZ staff for their technical assistance. This work was supported by the Ministerio de Ciencia y Tecnología (Spain) and the Junta de Castilla y León (Comunidad de Castilla y León, Spain). 


\section{References}

Cashion, P., Holder-Franklin, M. A., McCully, J. \& Franklin, M. (1977). A rapid method for the base ratio determination of bacterial DNA. Anal Biochem 81, 461-466.

De Ley, J., Cattoir, H. \& Reynaerts, A. (1970). The quantitative measurement of DNA hybridization from renaturation rates. Eur $J$ Biochem 12, 133-142.

De Soete, G. (1983). A least squares algorithm for fitting additive trees to proximity data. Psychometrika 48, 621-663.

Doetsch, R. N. (1981). Determinative methods of light microscopy. In Manual of Methods for General Bacteriology, pp. 21-33. Edited by P. Gerdhardt, R. G. E. Murray, R. N. Costilow, E. W. Nester, W. A. Wood, N. R. Krieg \& G. B. Phillips. Washington, DC: American Society for Microbiology.

Fitch, W. M. (1972). Toward defining the course of evolution: minimum change for a specific tree topology. Syst Zool 20, 406-416.

Hasegawa, T., Takizawa, M. \& Tanida, S. (1983). A rapid analysis for chemical grouping of aerobic actinomycetes. J Gen Appl Microbiol 29, 319-322.

Hirsch, P., Mevs, U., Kroppenstedt, R. M., Schumann, P. \& Stackebrandt, E. (2004). Cryptoendolithic actinomycetes from Antarctic sandstone rock samples: Micromonospora endolithica sp. nov. and two isolates related to Micromonospora coerulea Jensen 1932. Syst Appl Microbiol 27, 166-174.

Huß, V. A. R., Festl, H. \& Schleifer, K. H. (1983). Studies on the spectrophotometric determination of DNA hybridisation from renaturation rates. Syst Appl Microbiol 4, 184-192.

Jahnke, K.-D. (1992). BASIC computer program for evaluation of spectroscopic DNA renaturation data from GILFORD SYSTEM 2600 spectrophotometer on a PC/XT/AT type personal computer. J Microbiol Methods 15, 61-73.

Kasai, H., Tamura, T. \& Harayama, S. (2000). Intrageneric relationships among Micromonospora species deduced from gyrBbased phylogeny and DNA relatedness. Int J Syst Evol Microbiol 50, 127-134.

Kawamoto, I. (1989). Genus Micromonospora Ørskov 1923, $147^{\mathrm{AL}}$. In Bergey's Manual of Systematic Bacteriology, vol. 4, pp. 2442-2450. Edited by S. T. Williams, M. E. Sharpe \& J. G. Holt. Baltimore: Williams \& Wilkins.

Koch, C., Kroppenstedt, R. M. \& Stackebrandt, E. (1996). Intrageneric relationships of the actinomycete genus Micromonospora. Int J Syst Bacteriol 46, 383-387.

Kumar, S., Tamura, K., Jakobsen, I. B. \& Nei, M. (2001). MEGA2: molecular evolutionary genetics analysis software. Bioinformatics 17, 1244-1245.

Lechevalier, M. P., De Bièvre, C. \& Lechevalier, H. (1977). Chemotaxonomy of aerobic actinomycetes: phospholipid composition. Biochem Syst Ecol 5, 249-260.

Lee, S. D., Goodfellow, M. \& Hah, Y. C. (1999). A phylogenetic analysis of the genus Catellatospora based on 16S ribosomal DNA sequences, including transfer of Catellatospora matsumotoense to the genus Micromonospora as Micromonospora matsumotoense comb. nov. FEMS Microbiol Lett 178, 349-354.

Lozano, J. C., Blanco Rodríguez, P. \& Tome, F. V. (2002). Distribution of long-lived radionuclides of the $238 \mathrm{U}$ series in the sediments of a small river in a uranium mineralized region of Spain. J Environ Radioact 63, 153-171.

Lüdemann, G. M. \& Brodsky, B. C. (1963). Taxonomy of gentamicin-producing Micromonospora. Antimicrob Agents Chemother 161, 116-124.

Mandel, M. \& Marmur, J. (1968). Use of ultraviolet absorbance temperature profile for determining the guanine plus cytosine content of DNA. Methods Enzymol 12B, 195-206.

Minnikin, D. E., O'Donnell, A. G., Goodfellow, M., Alderson, G., Athalye, M., Schaal, K. \& Parlett, J. H. (1984). An integrated procedure for extracting bacterial isoprenoid quinones and polar lipids. J Microbiol Methods 2, 233-241.

Orskov, J. (1923). Investigations into the Morphology of the Ray Fungi. Copenhagen: Levin \& Munksgaard.

Rhuland, L. E., Work, E., Denman, R. F. \& Hoare, D. S. (1955). The behavior of the isomers of $\alpha, \varepsilon$-diaminopimelic acid on paper chromatograms. J Am Chem Soc 77, 4844-4846.

Rivas, R., Sánchez, M., Trujillo, M. E., Zurdo-Piñeiro, J. L., Mateos, P. F., Martínez-Molina, E. \& Velázquez, E. (2003). Xylanimonas cellulosilytica gen. nov., sp. nov., a xylanolytic bacterium isolated from a decayed tree (Ulmus nigra). Int J Syst Evol Microbiol 53, 99-103.

Saitou, N. \& Nei, M. (1987). The neighbor-joining method: a new method for reconstructing phylogenetic trees. Mol Biol Evol 4, 406-425.

Schleifer, K. H. \& Kandler, O. (1972). Peptidoglycan types of bacterial cell walls and their taxonomic implications. Bacteriol Rev 36, 407-477.

Schröder, K.-H., Naumann, L., Kroppenstedt, R. M. \& Reischl, U. (1997). Mycobacterium hassiacum sp. nov., a new rapidly growing thermophilic mycobacterium. Int J Syst Bacteriol 47, 86-91.

Staneck, J. L. \& Roberts, G. D. (1974). Simplified approach to the identification of aerobic actinomycetes by thin-layer chromatography. Appl Microbiol 28, 226-231.

Trujillo, M. E., Velázquez, E., Kroppenstedt, R. M., Schumann, P., Rivas, R., Mateos, P. F. \& Martínez-Molina, E. (2004). Mycobacterium psychrotolerans sp. nov., isolated from pond water near a uranium mine. Int J Syst Evol Microbiol 54, 1459-1463.

Wayne, L. G., Brenner, D. J., Colwell, R. R. \& 9 other authors (1987). International Committee on Systematic Bacteriology. Report of the ad hoc committee on reconciliation of approaches to bacterial systematics. Int J Syst Bacteriol 37, 463-464.

Williams, S. T., Goodfellow, M., Alderson, G., Wellington, E. M. H., Sneath, P. H. A. \& Sackin, M. J. (1983). Numerical classification of Streptomyces and related genera. J Gen Microbiol 129, 1743-1813. 